\title{
A step backward for Italy's meritocracy.
}

Ignazio Roberto Marino

Thomas Jefferson University

Follow this and additional works at: https://jdc.jefferson.edu/surgeryfp

Part of the Surgery Commons

Let us know how access to this document benefits you

\section{Recommended Citation}

Marino, Ignazio Roberto, "A step backward for Italy's meritocracy." (2012). Department of

Surgery Faculty Papers. Paper 59.

https://jdc.jefferson.edu/surgeryfp/59

This Article is brought to you for free and open access by the Jefferson Digital Commons. The Jefferson Digital Commons is a service of Thomas Jefferson University's Center for Teaching and Learning (CTL). The Commons is a showcase for Jefferson books and journals, peer-reviewed scholarly publications, unique historical collections from the University archives, and teaching tools. The Jefferson Digital Commons allows researchers and interested readers anywhere in the world to learn about and keep up to date with Jefferson scholarship. This article has been accepted for inclusion in Department of Surgery Faculty Papers by an authorized administrator of the Jefferson Digital Commons. For more information, please contact: JeffersonDigitalCommons@jefferson.edu. 


\title{
As submitted to:
}

\section{Science}

\section{And later published as:}

\section{A Step Backward for Italy's Meritocracy}

\author{
May 4 2012; Volume 336, Issue 6081, page: 541
}

\section{IGNAZIO ROBERTO MARINO}

\begin{abstract}
Department of Surgery, Jefferson Medical College, Philadelphia, PA 19107, USA, and Senate of the Republic of Italy, Piazza Madama snc, 00186 Rome, Italy. E-mail: ignazio.marino@jefferson.edu
\end{abstract}

Italian scientists have long lamented the lack of resources, political attention, and meritocracy in assigning taxpayers' money.

In 2007, things began to change. The 2007 and 2008 national budget laws allocated $€ 81$ million (US $\$ 107$ million) to projects submitted by researchers under 40 years old. They were judged by an international committee of scientists under age 40 that was appointed according to impact factor and citation index scores. Even though this fund accounted for only $10 \%$ of the entire public research money, it was a crucial turning point toward meritocracy. Finally, the international rules of peer review were entering the Italian system, acknowledging meritocracy and setting researchers free from the virtual servitude under which they had been kept by old academicians.

Recently, inexplicably, Italy has fallen back to the old way of allocating taxpayers' research money and has done so in spite of government promises of open competition and meritocracy. The so-called "Simplification Decree" includes anti-crisis measures suggested by several departments, including the one led by the Minister of Education, University, and Research: Francesco Profumo. He has canceled the articles of the laws that brought peer review to Italy, explaining that the method introduced in 2007 was too cumbersome to apply. Minister Profumo now promises a new, simpler law, but for the time being, young researchers applying for grants in Italy will have to rely on the old questionable, nontransparent evaluation method that rewards clients of godfathers, rather than merit.

It is not only money for valuable researchers that will be lacking from now on, but hope for their future and for that of the country. The only way out is to adopt strict peer-review rules for the allocation of all research funds, at all times. 